\title{
The Release of EGF Domain from EGF-like Factors by a Specific Cleavage Enzyme Activates the EGFR-MAPK3/1 Pathway in Both Granulosa Cells and Cumulus Cells During the Ovulation Process
}

\author{
Yasuhisa YAMASHITA ${ }^{1)}$ and Masayuki SHIMADA ${ }^{2)}$ \\ 1) Laboratory of Animal Physiology, Faculty of Life and Environmental Sciences, Prefectural University of Hiroshima, \\ Hiroshima 727-0028, Japan \\ 2) Laboratory of Reproductive Endocrinology, Graduate School of Biosphere Science, Hiroshima University, \\ Hiroshima 739-8528, Japan
}

\begin{abstract}
In mammalian preovulatory follicles, LH stimulation induces the ovulation process, including follicular wall rupture, granulosa cell luteinization, cumulus cell expansion and meiotic maturation of the oocyte. The receptor for LH (LHCGR) is expressed mostly in granulosa cells of preovulatory follicles, and is rarely expressed in cumulus cells or oocytes. The expression level in granulosa cells dramatically decreases after ovulation stimuli. Thus, a potent factor(s) secreted by granulosa cells is required to stimulate not only granulosa cells via an autocrine manner but also cumulus cells and/or oocytes via a paracrine pathway. Recent reports showed that granulosa cells and cumulus cells express EGF-like factors that activate the EGF receptor (EGFR)-mitogen-activated protein kinase3/1 (MAPK3/1) (also known as extracellular signal-regulated kinase1/2 (ERK1/2)) pathway in both cell types. EGF-like factors are composed of a signal sequence, transmembrane domain and EGF domain, suggesting that release of the EGF domain by a specific enzyme is essential for interaction with the EGFR to induce the ovulation process. In our studies, TACE/ADAM17, which is known to be a proteolytic enzyme of EGF-like factors in many types of tissue, was found to be expressed in FSH/LH-stimulated granulosa cells and cumulus cells together with activation of the EGFR-MAPK3/1 pathway. When TACE/ADAM17 activity was decreased by a specific inhibitor or siRNA technique, granulosa cell luteinization, cumulus expansion and oocyte maturation were suppressed in an in vitro culture. Thus, TACE/ADAM17 is one of the key genes expressed in both granulosa cells and cumulus cells for induction of the ovulation process.
\end{abstract}

Key words: cAMP, EGF like factors, PGE2, Progesterone, Ovulation

(J. Reprod. Dev. 58: 510-514, 2012)

$\mathbf{T}$ he surge of LH from the pituitary gland stimulates preovulatory follicles, and the stimulus induces a series of ovulation processes: follicular wall rupture, granulosa cell luteinization, cumulus expansion and meiotic maturation of the oocyte. Because the receptor for $\mathrm{LH}$ (LHCGR) is dominantly expressed in granulosa cells and is dramatically broken-down after an LH surge [1], a potential factor(s) secreted from granulosa cells to interact with granulosa cells, cumulus cells or oocytes must be required to induce these events [2].

Recently, Conti and coworkers conducted global mRNA expression profiling of mouse granulosa cells in response to PMSG and subsequent hCG stimuli. The results showed that the expression levels of EGF-like factors, amphiregulin (AREG), epiregulin (EREG) and $\beta$-cellulin (BTC) were significantly upregulated by hCG in granulosa cells, and addition of these factors to maturation medium enhanced cumulus cell expansion and meiotic maturation of follicle-enclosed mouse oocytes [3]. EGF-like factors act on EGFR to activate the RasMAPK3/1 pathway in granulosa cells and cumulus cells. Granulosa cell-specific and cumulus cell-specific mutation of the Erk1/2 gene

Received: March 14, 2012

Accepted: May 4, 2012

(C)2012 by the Society for Reproduction and Development

Correspondence: Y Yamashita (e-mail: yamayasu@pu-hiroshima.ac.jp)

and M Shimada (e-mail: mashimad@hiroshima-u.ac.jp)

impairs oocyte maturation, cumulus expansion and granulosa cell luteinization $[4,5]$, indicating that EGF-like factors are one of the key factors likely to work as autocrine factors in granulosa cells, and transmit the LH-dependent signal from granulosa cells to cumulus cells and the oocyte.

EGF-like factors are transmembrane proteins comprising a signal sequence, a transmembrane domain and at least one EGF domain. To activate cognate receptors by EGF-like factors working as a ligand, metalloprotease activity is critical for release of the EGF domain. Importantly, Sahin et al. [8] showed that tumor necrosis factor $\alpha$-converting enzyme (TACE) is the main sheddase of AREG and EREG in mouse embryonic cells. TACE, which is also known as ADAM17, is a member of the ADAM (a disintegrin and metalloprotease) family of proteases. Expression of TACE/ADAM17 has been observed in many tissues, including the heart, brain, lung, liver, muscle, kidney and testis. Although mechanisms of EGF-like factor expression during the ovulation process have been reported [6, 7], until recently there was little information about how to specifically activate these factors as ligands, especially regarding the expression and functional roles of TACE/ADAM17. This mini-review focuses on mechanisms underlying the expression and activation of TACE/ ADAM17 and its physiological roles in granulosa cells and cumulus cells during the oocyte maturation process. 


\section{Expression of TACE/ADAM17 in Granulosa and Cumulus Cells}

TACE/ADAM17 belongs to the ADAM family of proteins, which currently comprises more than 30 members. About $50 \%$ of ADAM proteins are expressed predominantly in the testis and play a role in spermatogenesis and fertilization. The others are involved in neurogenesis, myogenesis, and osteogenesis, and in the regulation of immune responses [9-11]. Unlike other types of ADAM protein, Tace/Adam 17 mRNA is ubiquitously expressed in numerous tissues [12]; however, a high level of expression is observed in cancer cells, where it is involved in activation of the EGFR-MAPK3/1 pathway to induce cell proliferation and migration. As in cancer cells, the EGFR-MAPK3/1 pathway is transiently and dramatically activated in granulosa cells and cumulus cells during the ovulation process due to the expression of EGF-like factors. From the above information, we hypothesized that TACE/ADAM17 might be expressed in granulosa cells and cumulus cells, where it might work as a shedding enzyme on EGF-like factors during the ovulation process.

Using mRNA recovered from granulosa cells or cumulus cells of antral follicles, preovulatory follicles, and periovulatory follicles of eCG/hCG-primed swine, we investigated the temporal changes in Tace/Adam 17 expression. The results revealed that administration of eCG to induce follicle development to the preovulatory stage did not increase the level of Tace/Adam 17 mRNA in either granulosa or cumulus cells, whereas mRNA expression was significantly induced by subsequent hCG stimuli [13].

To clarify how Tace/Adam 17 is expressed during the ovulation process, in vitro culture studies of granulosa cells and cumulus-oocyte complexes (COCs) were carried out. Treatment with FSH and/or LH also increased the expression level of Tace/Adam 17 mRNA in both cell types, concomitantly with Areg and Ereg mRNA expression. Western blotting analysis also showed upregulation of the protein by FSH and LH in cumulus cells of COCs [14]. Furthermore, expression of Tace/Adam17 was significantly suppressed by inhibitors of the PKA, p38MAPK (MAPK14) or MAPK3/1 pathway [15]. Its proximal promoter contains multiple AP2 and Sp1 transcription factor binding sites and includes a GC box and a CCAAT box; thus the region including both boxes has potential promoter activity [16]. $\mathrm{C} / \mathrm{EBP} \alpha$ and $\mathrm{C} / \mathrm{EBP} \beta$, which directly bind to a CCAAT box in promoter regions, are well-known targets of MAPK3/1; however, they are also activated by both PKA and p38MAPK. Following LH stimuli, PKA and p38MAPK are rapidly activated by a nongenomic pathway within $1 \mathrm{~h}$, and then phosphorylation of MAPK3/1 is induced by an EGF-like factor expressed in mouse granulosa cells [17]. Thus, TACE/ ADAM17 expressed by PKA- and p38MAPK-dependent mechanisms releases the EGF domain from EGF-like factors, which then increase the phosphorylation level of MAPK3/1. The MAPK3/1-C/EBP pathway further increases the expression level of TACE/ADAM17 to maintain the activation status of the signaling pathway (Fig. 1). This positive feedback system is required to induce a successful ovulation process as follows.

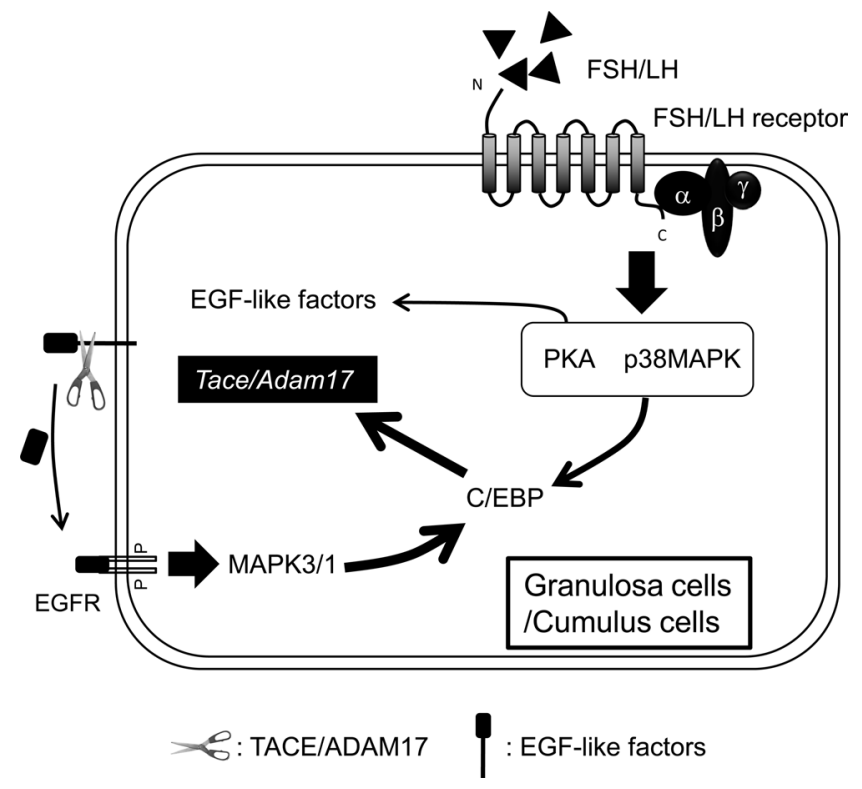

Fig. 1. The mechanism of TACE/ADAM17 expression in granulosa cells and cumulus cells. FSH/LH stimuli activates the PKA- and p38MAPK-C/EBP pathway, and then induces Tace/Adam17 mRNA expression in granulosa cells and cumulus cells. The EGF-like factors released by TACE/ADAM17 activate the EGFR-MAPK3/1-C/EBP pathway, which results in the increase in Tace/Adam17 mRNA level in granulosa cells and cumulus cells during the ovulation process.

\section{Function of TACE/ADAM17 in Granulosa and Cumulus Cells}

The metalloproteinase domain of TACE/ADAM17 contains the zinc-binding consensus motif (HWLGHNFGAEHD) involved in coordinating zinc with histidine residues and creating the active site of the enzyme $[12,18]$. In many tissues and cell types, TACE/ADAM17 has been reported to have putative substrates, including transforming growth factor- $\alpha$ (TGF $\alpha$ ), heparin-binding EGF (HB-EGF), Notch, AREG and EREG $[8,19]$. In the mouse ovary, the expression level of TGF $\alpha$ and HB-EGF is low and dose not change during follicular development and ovulation [20], indicating that these factors are not the potential target proteins of TACE/ADAM17. Johnson et al. [21] reported that Notch mRNA was detected in response to PMSG stimuli in growing follicles, although the functional role of Notch in the oocyte maturation process has not yet been demonstrated.

It has been shown that Areg and Ereg are expressed in granulosa and cumulus cells during the ovulation process [3, 17], and their induction is observed concomitantly with the increase in Tace/Adam 17 mRNA level [14, 15], suggesting that AREG and EREG might be physiological substrates of TACE/ADAM17 in periovulatory follicles. When porcine COCs were cultured for up to $40 \mathrm{~h}$, the enzyme activity of TACE/ADAM17 was upregulated by gonadotropins as compared with cumulus cells of COCs before culture [14]. Phosphorylation of MAPK3/1 was induced by the addition of EGF or gonadotropins (FSH+LH) to cumulus cells of COCs. This phosphorylation of MAPK3/1 was completely downregulated by 
addition of the TACE/ADAM17 selective inhibitor, TAPI-2, when porcine COCs or granulosa cells were cultured with FSH and $\mathrm{LH}$ [14]. However, these inhibitory effects were not observed in COCs or granulosa cells with EGF-like factors. In addition, we showed that LH-induced phosporylation of MAPK3/1 was suppressed by transfection with Tace/Adam 17 siRNA in rat granulosa cells [14]. Thus, TACE/ADAM17 expressed in granulosa cells and cumulus cells facilitates release of the EGF domain of EGF-like factors, which then activates the EGFR-MAPK3/1 pathway in cumulus cells and granulosa cells during the ovulation process.

\section{Positive Feedback Loop of EGF-like Factors, TACE/ ADAM17 and PGE2 in Cumulus Cells of Porcine COCs}

Prostaglandin E2 (PGE2) is synthesized and accumulates within the follicular fluid of periovulatory follicles. Mice deficient in Ptgs 2 (encoding cyclooxygenase-2; COX-2) or Pger2 (encoding PGE2 receptor 2, PGER2) show a decreased number of ovulated oocytes and complete loss of fertilization ability [22]. Importantly, our previous study showed the downregulation of EGF-like factor expression in Ptgs2-deficient mice during administration of hCG. Interestingly, the expression of Ptgs 2 was upregulated by EGF-like factors [17], strongly indicating the existence of a positive feedback system between EGF-like factors and PGE2 during the ovulation process.

In an in vitro culture system of porcine COCs, expression of Ptgs 2 and Ptger 2 was induced by FSH concomitant with Areg, Ereg and Tace/Adam 17 expression [23]. The expression of Areg, Ereg and Tace/Adam 17 was significantly downregulated by the PTGS2 inhibitor, NS398, in cumulus cells of COCs cultured for $10 \mathrm{~h}$, but not in those cultured for $5 \mathrm{~h}$. During in vitro maturation of porcine COCs, the cAMP level was dramatically increased within $5 \mathrm{~h}$, and this level was then maintained for up to $40 \mathrm{~h}$ [24]. However, the level of Fshr mRNA that encoded the FSH receptor was rapidly and significantly decreased in cumulus cells of COCs cultured with FSH alone [23], suggesting that other stimulators that increase the cAMP level in cumulus cells must be secreted from cumulus cells. Strikingly, the cAMP level was not changed by NS398 at $5 \mathrm{~h}$, whereas it was significantly decreased at $10 \mathrm{~h}$. Furthermore, NS398 dramatically suppressed MAPK $3 / 1$ after $10 \mathrm{~h}$ of culture but not after $5 \mathrm{~h}$ of culture. The addition of PGE2 alone induced cumulus expansion and/or oocyte meiotic maturation not only in pigs but also in mice $[25,26]$, indicating that PGE2 is the second factor that acts on cumulus cells to maintain the high level of cAMP. The results demonstrate that the initial expression of EGF-like factors and TACE/ADAM17 is induced in a gonadotropin-dependent manner, whereas sustainable expression of EGF-like factors and TACE/ADAM17 is dependent on the PGE2-PGER2 pathway [23] (Fig. 2).

\section{Terminal Regulation of TACE/ADAM17 Expression by the PGR Pathway in Cumulus Cells of Porcine COCs}

Progesterone is synthesized and secreted during the ovulation process and formation process of the corpus luteum. Mice deficient in $N r 3 c 3$ (encoding the progesterone receptor, PGR) fail to ovulate $[27,28]$; however, histological analysis of the ovaries of these mice revealed that cumulus expansion is normally induced after
hCG injection. On the other hand, our previous studies showed that pharmacological inhibition of PGR or progesterone production during in vitro maturation of porcine COCs dramatically suppresses both cumulus expansion and oocyte maturation [29-32]. In addition, when one $\mathrm{COC}$ was cultured in each well, oocyte meiotic resumption was delayed as compared with wells where 20 COCs were cultured. The level of progesterone in the medium was raised by increasing the number of COCs in each well [33], suggesting that the progesteronePGR pathway is required to induce cumulus expansion and oocyte maturation in pig COCs, at least in in vitro culture.

To clarify the roles of the progesterone-PGR pathway in more detail, we focused on the EGFR-MAPK3/1 pathway. Addition of the PGR antagonist, RU486 did not affect FSH-induced Areg and Ereg expression at any cultivation time point. RU486 also did not affect Tace/Adam 17 mRNA expression in cumulus cells of COCs cultured up to $20 \mathrm{~h}$; at 30 or $40 \mathrm{~h}$, however, RU486 significantly suppressed Tace/Adam 17 mRNA expression. Although the phosphorylation level of MAPK3/1 and expression of its target genes (Has 2 and Tnfaip6) were not affected by RU486 up to $20 \mathrm{~h}$, these levels were dramatically suppressed by RU486 at $40 \mathrm{~h}$. Furthermore, cumulus expansion and the percentage of oocytes reaching the MII stage were also suppressed by RU486. Thus, the results indicated that the progesterone-PGR pathway regulates the expression level of Tace/ Adam 17 during late cumulus expansion but not the levels of EGF-like factors, which are essential for the terminal secretion of EGF-like factors during cumulus expansion and oocyte meiotic maturation in pigs [34] (Fig. 2). However, because the promoter region of the Tace/ Adam 17 gene dose not contain the progesterone responsive element (PRE) [16], further study is required to understand how terminal Tace/Adam 17 gene expression is regulated by the progesterone-PGR pathway during this phase.

\section{Conclusion}

EGF-like factors are the most important and potent factors that enhance oocyte maturation and ovulation. Our studies have focused on the mechanisms that activate EGF-like factors. We have shown that the high expression of Tace/Adam 17 in granulosa and cumulus cells of porcine COCs is induced in a PGE2-dependent manner. The sequential induction of EGF-like factors enhances activation of MAPK3/1 in cumulus cells. Furthermore, we revealed that the progesterone-PGR pathway is required for maintenance of Tace/ Adam 17 mRNA gene expression, but not for maintenance of the gene expression of EGF-like factors, in order to sustain MAPK3/1 activation in late cumulus expansion. In summary, activation of the EGFR-MAPK3/1 pathway via a TACE/ADAM17-released EGF domain from an EGF-like factor induces cumulus expansion and oocyte maturation in porcine COCs.

\section{Acknowledgements}

Dr JS Richards and Dr M Hishinuma provided us with outstanding assistance and good suggestions. This work was supported in part by Grants-in-Aid for Scientific Research No. 19880020 and No. 22780251 (Y Y), and No. 21688019, No. 21028015 and No. 21248032 (M S) from the Japan Society for the Promotion of Sci- 


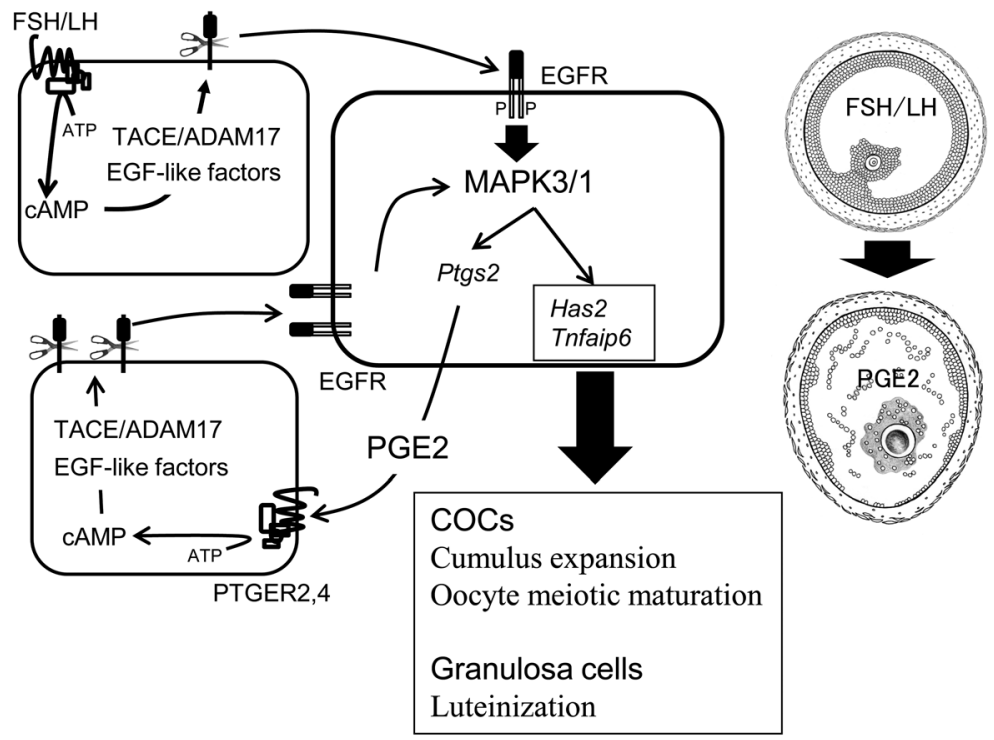

Fig. 2. The expressions of TACE/ADAM17 and EGFlike factors in granulosa cells and cumulus cells during the ovulation process. FSH/LH stimuli induce EGF-like factor and TACE/ADAM17 expressions via a cAMP-dependent pathway in granulosa cells and cumulus cells. The EGF-like factors released by TACE/ADAM17 activate the EGFR-MAPK3/1 pathway, which enhances the expression of Ptgs $2 \mathrm{mRNA}$ in granulosa cells and cumulus cells. The produced PGE2 acts on PTGER2/4 and induces the maximum level of EGF-like factors and TACE/ADAM17 expressions in both types of cells, which results in the induction of sustainable activation of MAPK3/1 during the ovulation process. The sustainable activation of MAPK3/1 induces cumulus expansion, oocyte meiotic maturation and luteinization of granulosa cells during the ovulation process.

Granulosa cells and cumulus cells

ence (JSPS). Porcine FSH was kindly provided by Dr AF Parlow, National Hormone and Pituitary Program, National Institute of Diabetes and Digestive and Kidney Diseases, USA. We thank Dr R Nishimura, Dr T Okazaki, Dr I Kawashima, Mr T Mizukami, Mr T Koike, Ms M Okamoto, Ms R Iyori and Mr H Mitsufuji for technical assistance, and the staff of the Meat Inspection Office in Tottori Prefecture and Hiroshima City for supplying the porcine ovaries.

\section{References}

1. Peng XR, Hsueh AJ, LaPolt PS, Bjersing L, My T. Localization of Luteinizing hormone receptor messenger ribonucleic acid and expression in ovarian cell types during follicle development and ovulation. Endocrinology 1991; 129: 3200-3207. [Medline] [CrossRef]

2. Gilula NB, Wpstein ML, Beers WH. Cell-to-cell communication and ovulation. A study of the cumulus-oocyte complex. J Cell Biol 1978; 78: 58-75. [Medline] [CrossRef]

3. Park JY, Su YQ, Ariga M, Law E, Jin SL, Conti M. EGF-like growth factors as mediators of LH action in the ovulatory follicles. Science 2004; 303: 682-684. [Medline] [CrossRef]

4. Fan HY, Lui Z, Shimada M, Sterneck E, Johnson PF, Hedrick SM, Richards JS. MAPK3/1 (ERK1/2) in ovarian granulosa cells are essential for female fertility. Science 2009; 324: 938-941. [Medline] [CrossRef]

5. Hsieh M, Thao K, Conti M. Genetic dissection of epidermal growth factor receptor signaling during luteinizing hormone-induced oocyte maturation. PLoS One 2011; 6: e21574. [Medline] [CrossRef]

6. Fan HY, O'Connor A, Shitanaka M, Shimada M, Lui Z, Richards JS. Beta-catenin (CTNNB1) promotes preovulatory follicular development but represses LH-mediated ovulation and luteinization. Mol Endocrinol 2010; 24: 1529-1542. [Medline] [CrossRef]

7. Sekiguchi T, Mizutani T, Yamada K, Yazawa T, Kawata H, Yoshino M, Kajitani T, Kameda T, Minegishi T, Miyamoto K. Transcriptional regulation of the epiregulin gene in the rat ovary. Endocrinology 2002; 143: 4718-4729. [Medline] [CrossRef]

8. Sahin U, Weskamp G, Kelly K, Zhou HM, Higashiyama S, Peschon J, Hartmann D, Saftig P, Blobel CP. Distinct roles for ADAM10 and ADAM17 in ectodomain shedding of six EGFR ligands. J Cell Biol 2004; 164: 769-779. [Medline] [CrossRef]

9. Turner AJ, Hopper NM. Role of ADAM-family proteinase as membrane protein secretases. Biochem Soc Trans 1999; 27: 255-259. [Medline]
10. Yamamoto S, Higuchi Y, Yoshiyama K, Shimizu E, Kataoka M, Hijiya N, Matsuura K. ADAM family proteins in the immune system. Immunol Today 1999; 20: 278-284. [Medline] [CrossRef]

11. Primakoff P, Myles DG. The ADAM gene family: surface protein with adhesion and protease activity. Trends Genet 2000; 16: 83-87. [Medline] [CrossRef]

12. Black RA, Rauch CT, Kozlosky CJ, Peschon JJ, Slack JL, Wolfson MF, Castner BJ, Stoching KL, Reddy P, Srinivasan S, Nelson N, Boiani N, Schooley KA, Gerhart M, Davis R, Fitzner JN, Johnson RS, Paxton RJ, March CJ, Cerretti DP. A metalloproteinase disintegrin that releases tumor-necrosis factor-alpha from cells. Nature 1997; 385 729-733. [Medline] [CrossRef]

13. Kawashima I, Okazaki T, Noma N, Nishibori M, Yamashita Y, Shimada M. Sequential exposure of porcine cumulus cells to FSH and/or LH is critical for appropriate expression of steroidogenic and ovulation-related genes that impact oocyte maturation in vivo and in vitro. Reproduction 2008; 136: 9-21. [Medline] [CrossRef]

14. Yamashita Y, Kawashima I, Yanai Y, Nishibori M, Richards JS, Shimada M. Horomen-induced expression of tumor necrosis factor alpha-converting enzyme/A disintegrin and metalloprotease-17 impacts porcine cumulus cell oocyte complex expression and meiotic maturation via ligand activation of the epidermal growth factor receptor. Endocrinology 2007; 148: 6164-6175. [Medline] [CrossRef]

15. Yamashita Y, Hishinuma M, Shimada M. Activation of PKA, p38MAPK and ERK1/2 by gonadotropins in cumulus cells is critical for induction of EGF-like factor and TACE ADAM17 gene expression during in vitro maturation of porcine COCs. J Ovarian Res 2009; 24: 2: 20. [Medline]

16. Mizui Y, Yamazaki Y, Tanaka I. cDNA cloning of mouse tumor necrosis factor-alpha converting enzyme (TACE) and partial analysis of its promoter. Gene 1999; 233: 67-74 [Medline] [CrossRef]

17. Shimada M, Hernandez-Gonzalez I, Gonzalez-Robanya I, Richards JS. Paracrine and autocrine regulation of epidermal growth factor-like factors in cumulus oocyte complexes and granulosa cells: key roles for prostaglandin synthase 2 and progesterone receptor. $\mathrm{Mol}$ Endocrinol 2006; 20: 1352-1365. [Medline] [CrossRef]

18. Moss ML, Jin SL, Milla ME, Bickett DM, Burkhart W, Carter HL, Chen WJ, Clay WC, Didsbury JR, Hassler D, Hoffman CR, Kost TA, Lambert MH, Leesnitzer MA, McCauley P, McGeehan G, Mitchell J, Moyer M, Pahel G, Rocque W, Overton LK, Schoenen F, Seaton T, Su JL, Becherer JD. Cloning of a disintegrinmetalloptroteinase that processes precursor tumor-necrosis factor-alpha. Nature 1997; 385: 733-736. [Medline] [CrossRef]

19. Mezyk R, Bzowska M, Bereta J. Structure and functions of tumor necrosis factor-alpha converting enyme. Acta Biochim Pol 2003; 50: 625-645. [Medline]

20. Conti M, Hsieh M, Park JY, Su YQ. Role of the epidermal growth factor network in 
ovarian follicles. Mol Endocrinol 2006; 20: 715-723. [Medline] [CrossRef]

21. Johnson J, Espinoza T, McGaughey RW, Rawis A, Wilson-Rawis J. Notch pathway genes are expressed in mammalian ovarian follicles. Mech Dev 2001; 109: 355-361. [Medline] [CrossRef]

22. Matsumoto H, Ma W, Smalley W, Trzaskos J, Breyer RM, Dey SK. Diversification of cyclooxygenase-2-derived prostagrandins in ovulation and implantation. Biol Reprod 2001; 64: 1557-1565. [Medline] [CrossRef]

23. Yamashita Y, Okamoto M, Kawashima I, Okazaki T, Nishimura R, Gunji Y, Hishinuma M, Shimada M. Positive feedback loop between prostagrandin E2 and EGFlike factors is essential for sustainable activation of MAPK $3 / 1$ in cumulus cells during in vitro maturation of porcine cumulus oocyte complexes. Biol Reprod 2011; 85: 1073-1082. [Medline] [CrossRef]

24. Shimada M, Terada T. Roles of cAMP in regulation of both MAP kinase ad p34(cdc2) kinase activity during meiotic progression, especially beyond the MI stage. Mol Reprod Dev 2002; 62: 124-131. [Medline] [CrossRef]

25. Goverde HJ. The enhancement by prostaglandin E2 of cumulus cell outgrowth in vitro. Prostaglandins 1993; 45: 241-247. [Medline] [CrossRef]

26. Takahashi T, Morrow JD, Wang H, Dey SK. Cyclooxygenase-2-derived prostagrandin E2 directs oocyte maturation by differentially influencing multiple signaling pathways. $J$ Biol Chem 2006; 281: 37117-37129. [Medline] [CrossRef]

27. Lydon JP, DeMayo FJ, Funk CR, Mani SK, Hughes AR, Montgomery CA Jr, Shyamala G, Connely OM, O'Mally BW. Mice lacking progesterone receptor exhibit pleiotropic reproductive abnormalities. Genes Dev 1995; 9: 2266-2278. [Medline] [CrossRef]

28. Robker RL, Russell DL, Espey LL, Lydon JP, O'Malley BW, Richards JS. Progester- one-regulated gens in the ovulation process: ADAMTS-1 and cathepsin L proteases. Proc Natl Acad Sci USA 2000; 141: 2385-2391.

29. Shimada M, Terada T. FSH and LH induce progesterone production and progesterone receptor synthesis in cumulus cells: a requirement for meiotic resumption in porcine oocytes. Mol Hum Reprod 2002; 8: 612-618. [Medline] [CrossRef]

30. Shimada M, Nishibori M, Yamashita Y, Ito J, Mori T, Richards JS. Down-regulated of A disintegrin and metalloproteinase with thrombospondin-like repeats-1 by progesterone receptor antagonist is associated with impaired expansion of porcine cumulus-oocyte complexes. Endocrinology 2004; 145: 4603-4614. [Medline] [CrossRef]

31. Shimada M, Yamashita Y, Ito J, Okazaki T, Kawahata K, Nishibori M. Expression of two progesterone receptor isoforms in cumulus cells and their roles during meiotic resumption of porcine oocytes. J Mol Endocrinol 2004; 33: 209-225. [Medline] [CrossRef]

32. Yamashita Y, Nishibori M, Terada T, Isobe N, Shimada M. Gonadotropin-induced delta 14-reductase and delta 7-reductase gene expression in cumulus cells during meiotic resumption of porcine oocytes. Endocrinology 2005; 146: 186-194. [Medline] [CrossRef]

33. Yamashita Y, Shimada M, Okazaki T, Maeda T, Terada T. Production of progesterone from de novo-synthesized cholesterol in cumulus cells and its physiological role during meiotic resumption of porcine oocytes. Biol Reprod 2003; 68: 1193-1198. [Medline] [CrossRef]

34. Yamashita Y, Kawashima I, Gunji Y, Hishinuma M, Shimada M. Progesterone is essential for maintenance of Tace/Adam17 mRNA expression, but not EGF-like factor, in cumulus cells, which enhances the EGF receptor signaling pathway during in vitro maturation of porcine COCs. J Reprod Dev 2010; 56: 315-323. [Medline] [CrossRef] 